\title{
@థ®ఠ Zaratustra e o Fracasso Pedagógico ${ }^{1}$
}

\author{
Maria dos Remédios de Brito*
}

Resumo: O presente texto toma o Prólogo da obra Assim Falou Zaratustra, precisamente, aquilo que se pode chamar de fracasso pedagógico. $\mathrm{O}$ argumento é que Zaratustra não fracassa ao dialogar com o povo na praça do mercado, mas faz desse encontro o seu primeiro ato fundamental de formação e aprendizado.

Palavras-chave: Zaratustra; Formação; Fracasso Pedagógico.

\section{Zaratustra y el fracaso pegagogico}

Resumen: El presente texto toma el prólogo de la obra Así habló Zaratustra, precisamente, lo que podría llamarse el fracaso pedagogico. El argumento es que Zaratustra no fracasa deja de diálogo con las personas en la plaza del mercado, pero este encuentro su primer acto fundamental de la formación y el aprendizaje.

Palabras clave: Zaratustra; Formación; El fracaso pedagógico.

\section{Zarathustra and the pedagogical failure}

Abstract: The following text takes the prologue of Thus Spoke Zarathustra, precisely, that which may be called a pedagogical failure. The argument herein is

\footnotetext{
1 'Pedagógico é relativo à pedagogia, que tem como etimologia gr. Paidagõgía, direção ou educação da criança. Do lat. Paedagõga (lex), lei que serve de guia'. (Cf: Dicionário: HOUAISS, A; VILLAR, M. S, 2001, p. 2162) Contudo, gostaria de enfatizar que o termo "pedagógico" não será entendido neste trabalho como um conjunto de métodos, de direção, de técnicas de ensino e de condução. A sua utilização demanda, neste estudo, sentidos de criação, tornar-se, superar-se, ou seja, constituir-se. Dessa maneira, inspira uma perspectiva formativa. É assim que este termo pode ser lido neste texto, ou seja, toma uma leitura diferenciada do que seja a sua própria etimologia.

* Graduada em Filosofia pela Universidade Federal do Pará (UFPA); Doutora em Educação pela Universidade Metodista de Piracicaba (UNIMEP), Pós-doutora pela Universidade Estadual de Campinas (UNICAMP). Professora da Faculdade de Filosofia da Universidade Federal do Pará/Instituto de Filosofia e Ciências Humanas (UFPA).E-mail: mrb@ufpa.br ORCID: https://orcid.org/0000-0002-0478-5285
} 
that Zarathustra does not fail when he dialogues with people in the market square; instead he turns this encounter into his first fundamental act of formation and learning.

Keywords : Zarathustra; Formation; Pedagogical Failure

\section{PROÊMIO}

O presente ensaio faz alguns deslocamentos interpretativos da obra fundamental de Nietzsche Assim Falou Zaratustra ${ }^{2}$, considerado um texto filosófico da terceira fase do pensador. Toma-se como fio condutor o personagem central da obra, Zaratustra e seu processo de movimentação filosófica e educativa. Nietzsche não só apresenta a obra como filosófica, mas é possível percorrer, por seu universo de escrita, vários componentes interpretativos, inclusive o pedagógico.

Nesse sentido, Assim Falou Zaratustra também pode ser lida como um processo de formação, de aprendizado vivenciado pelo personagem central (Zaratustra). Zaratustra educa, não porque impõe regras, normas, condutas, leis, modos pragmáticos e pedagógicos. Não! Zaratustra educa pelo exercício processual singular, pelo exercício da experimentação de si e de sua filosofia. Com tal atividade destrona um modo de educação tão presente na modernidade, a educação universalista e utilitária. Em desacordo com sua época, sugere que se deve educar a si mesmo para

\footnotetext{
${ }^{2}$ Publicado em quatro partes, entre 1883 e 1885, Assim Falou Zaratustra (...) é o trabalho de Nietzsche que traz maiores dificuldades à interpretação. Nele, os ensinamentos e experiências do personagem,- título são apresentados como um drama em prosa, em cuja narrativa se combinam os mais variados elementos estéticos de gênero, forma e estilo. "Nietzsche explora ao infinito a rítmica, a sonoridade e os matizes da língua alemã, ao mesmo tempo, que recorre à encenação teatral, à formas diversas de narração, à poesia, ao canto, à dança, à sátira e à paródia, assim como, sobretudo, à intertextualidade (...) Assim Falou Zaratustra condensa efetivamente todos os focos de interesse que constituem o âmago do pensamento de Nietzsche: a desconstrução da metafísica, a denúncia da hipocrisia moral, as preocupações com a educação, a política e o destino da cultura, a crítica do Estado" (GIACOIA, 2001, p. 55).
} 
manter-se afastado de todo tipo de embuste e coisificação, como forma de pensar a favor de outros modos de vida e de existência.

A obra não se torna importante somente por sua filosofia madura, nem por apresentar uma linguagem extremamente refinada e uma estilística avançada, mas, principalmente, porque apresenta um pensamento demolidor e construtor, que exercita a base mais afirmativa do pensamento de Nietzsche.

O texto objetiva explicitar, por meio do Prólogo ${ }^{3}$, aquilo que se chama fracasso pedagógico, estando ligado efetivamente aos experimentos iniciais de Zaratustra. Com isso, será indagado: Zaratustra sofre um fracasso pedagógico com o povo na praça do mercado? Como Zaratustra vivencia tal experiência? De outro modo, como essa imagem pode ser inspiradora para o seu leitor?

É importante destacar que o movimento inicial de Zaratustra no Prólogo é simbolizado pelos dez anos em que o mesmo fica na montanha, quando ao abandonar sua terra natal rompe com o conforto do lar para, então, aprender a amar a solidão. É a partir de um ambiente que no primeiro momento lhe parece estranho - a montanha - que ocorre o eco de

\footnotetext{
${ }^{3} \mathrm{O}$ prólogo de Zaratustra foi escrito juntamente com a primeira parte do livro e mandado para a publicação em fevereiro de 1883 , o que poderia nos levar a supor que este valeria apenas para esta parte e não para as outras. Contudo, diz Héber Suffrin que ele pode muito bem ser visto como o corpo estrutural de todo o livro, pois "o prólogo constitui uma introdução sistemática, muito estruturada, ao conjunto de Zaratustra, um recenseamento dos problemas e um levantamento de todos os conceitos" (HÉBER-SUFFRIN, 1994, p. 8). Destaca-se que no prólogo Nietzsche apresenta os temas como: a morte de Deus, o alémdo-homem e o último-homem, temas estes que, como os discursos da primeira parte, são questões importantes para o entendimento do aprendizado de Zaratustra, pois este ensina, mas também aprende ao ensinar, mostrando que a educação, o aprendizado, não se configuram pelo repasse mecânico, mas o aprender, aqui, está efetivamente ligado às experiências e às vivências da vida, o que faz destacar o repensar do que seria ensinar e aprender.
} 
um sublime espírito, que, pelo esforço e força de desfazer o desligamento com tudo que é comum, pode produzir e conduzir a si mesmo.

O "si mesmo" não é postulado como uma propriedade de que se dispõe e se toma como controle, ou mesmo uma estabilidade para uma identidade, não é algo enclausurado pelos seus valores, sem que isto queira demandar um itinerário fixado. Como num trabalho de reconstituição, de vigoramento, ele aflora outros sentidos. Alimenta-se outra intelectualidade sob o ponto de vista de outros sabores e odores, a sua paixão torna-se maior e grandiosa. É, por isso, que a nobreza é posta como critério distintivo que põe Zaratustra em um patamar afirmativo.

É na manifestação da retirada do lugar familiar, é na caracterização da extrapolação ao ver o que está vulgarizado pela palavra, pela linguagem ou pelo costume, que ele efetiva outro olhar: não mais ver de lado, ou de baixo. Mas é de cima da montanha que Zaratustra percebe o que é "vulgarizado", o "ritualizado" pelas crenças e verdades que podem ser postas em outros eixos, inclusive a sua própria vida. Ir para a montanha já implica um processo de reflexão, portanto, é com o olhar de quem está de cima, que a visão, os sentidos podem ser ampliados.

O que leva a dizer que o trabalho formativo não pode permitir ser viabilizado apenas de um lugar, de uma forma, de uma maneira, até porque isso não é possível, pois, quando se lida com o que é humano, escorre-se sempre pelos abismos. Ir para a montanha não é garantia, ele apenas quis dar mobilidade de constituir sobre si mesmo e sobre outros, a capacidade de ver em perspectiva, em experimento, já que, do "alto", o mundo, a vida podem ser configurados em pluralidades interpretativas, pois é com o voo do olhar, da reflexão que se podem transformar e criar - o "alto, "a montanha", "o acima".

Nesse sentido, não podem ser compreendidos como valores superiores ao terreno, pois Zaratustra não fala por oposição, mas como metáfora de alguém que está imbuído por sentimentos mais vigorosos. Para tal, é necessário fazer certo desvio de tudo que parece reto e mergulhar no sinuoso e nas incertezas. 
Portanto, a imagem metafórica da montanha mostra uma ampliação dos sentidos, ele vê em ângulos diferenciados, destacando que aquele que se permite caminhar e avançar sobre o seu si mesmo tem que estar preparado para ver as coisas sempre em outro foco. Não quer uma vida padrão, nem um método para ver o mundo da mesma forma. Impor esse tipo de conduta é matar todo o potencial criador de qualquer indivíduo.

Zaratustra aprendeu que a vida é um mar aberto, e aqueles que pretendem navegar na aventura de si mesmos devem compreender que as ondas sempre mudam. Por isso, não quer ser fixado.

Zaratustra abre-se como educador no instante em que inicia seu processo de experimentação de si. E ao se permitir fazer uso também da narrativa, visto que, não é só ele quem narra, caberia até mesmo perguntar quem é o narrador em Zaratustra, pois são tantos os que narram, mas ao contar seus dramas, sua história, sua vivência, mostra sua compreensão de mundo, de vida, faz, ao mesmo tempo, a sua crítica sobre todas as coisas que percebe ao seu redor.

Após esse processo de amadurecimento não é à toa que, numa certa manhã, faz todo um discurso de agradecimento ao sol $^{4}$ e, como ele, diz que precisa doar o seu supérfluo (Überflüssig), conta da necessidade de descer, pois está excedendo, há uma inexorável vibração em seu coração. Como o sol que ao entardecer deve partir, descer, ele quer isso. É exatamente por isso que: (...) devo baixar à profundeza: como fazes à

\footnotetext{
${ }^{4}$ Quanto ao discurso de agradecimento ao sol, que ocupa grande parte das reflexões de Zaratustra, diz Roberto Machado "essa referência ao sol é importante. Além da evidente paródia do mito platônico, em cuja caverna o sol não entra, a presença determinante do astro no início da trajetória de Zaratustra faz deste um personagem luminoso, resplandecente (...). Curt Paul Janz, cita, no entanto, uma carta de Nietzsche a Peter Gast, de 23 de abril de 1883, que diz: "Hoje, aprendi por acaso o significado de 'Zaratustra", isto é, estrela de ouro. Fiquei feliz com este acaso" (MACHADO, 1997 p. 36). Diz ainda Roberto Machado " (...) Zaratustra, no início de sua trajetória, é um personagem luminoso, resplandecente, fulgurante. Mas nem sempre foi assim. Este início assinala uma transformação, uma metamorfose. Como o sol que declina, o Zaratustra quer declinar, pois deseja dar e distribuir, quer descer, do mesmo modo que o sol faz à noite" (MACHADO, 1997. p.42).A descida de Zaratustra e seu declínio são para oferecer um presente aos homens, o além-do-homem.
} 
noite, quando vais para atrás do oceano e levas a luz também ao mundo inferior, ó astro opulente (überreich) (NIETZSCHE, 2011, p. 11). Quer a bênção deste astro iluminado.

Nota-se que Zaratustra não pergunta sobre a conservação e é essa sua vontade de amor que escorrega sobre si mesmo, seu compromisso se torna singular com a vida e, por isso, cumpre-lhe acolher a morte no seu seio $^{5}$, ou seja, ama o desaparecer, aqueles que não se preservam, que transbordam, que vão até o abismo, que se lançam para a vida, para o desconhecido, que não têm medo do erro. Porque, acima de tudo, amam a vida e sabem precipitar-se. Ele ama a sua própria descida.

Seu espírito está deliciado com outras intuições, interpretações, isto é claramente manifestado na alegria que sente com a luz e com o brilho, porque parece que ele mesmo viveu uma grande transformação, uma espécie de passagem (Übergang) do sol às cinzas e ao fogo, ou seja, ele mostra o seu cruzamento de formação; em vez das cinzas que levara para a montanha, ele, agora, quer levar fogo ao vale, sugerindo que o homem, por meio de sua força criadora, é mutável, está sempre aprendendo.

O seu coração está transformado, por isso, quer doar o seu supérfluo, que não pode ser visto como os restos de Zaratustra, mas é a dinâmica da sua própria vontade de vida. Neste primeiro momento, Zaratustra se mostra como um doador.

Ele discute, nessas suas primeiras narrativas, a experimentação como fator que viabiliza a superação ${ }^{6}$ do peculiar, da abstração das verdades, da crença dogmatizada, da mesquinharia, da falta de riqueza, da

\footnotetext{
${ }^{5}$ Verificar o texto O ateísmo como vontade de ocaso. (YAFAR, 2001, p. 145).

${ }^{6}$ A superação também foi sendo trabalhada na própria cena apresentada pelo afastamento de Zaratustra dos homens após ficar em sua montanha por 10 anos, preparando-se novamente. Quer agora, de maneira superada, abundante, dar um presente aos homens. Aqui, a superação não está ligada, como na segunda parte, à vida. Sobre a questão da superação, tão presente no texto de Assim Falou Zaratustra, para Wolfgang Müller-Lauter, no texto The Way to the Overman, o próprio Zaratustra ainda não fez a superação, ela aparece como se fosse uma bela sombra. Este tipo ainda é a sua procura. (MÜLLER-LAÜTTER, 1999, p 79).
} 
vida padronizada, dos ideais absolutizados, enfim, deve superar tudo que torne o homem sem querer.

Portanto, todo o seu perfil afirmativo e criador destacado é dominado não pela carência, mas pela abundância (Überfluss) ${ }^{7}$, pelo excesso de amor. Ao querer descer de sua montanha, ele remete à ideia de rasgar novamente o que é cotidiano, da convivência comum, mas isto não é feito por capricho, nem porque cansou de sua solidão, de sua sabedoria, ou de si mesmo, o que só o deixaria ser mais um homem nivelado. Ele identifica a sua segurança, que não é uma segurança qualquer, que esteja, por exemplo, calcada na produção material ou mesmo em verdades absolutas. Mas ela está ligada à mudança de perspectiva, por isso não quer esquivar-se do seu ocaso. E diz: devo ter o meu ocaso. ${ }^{8}$

Ele apresenta a queda, o seu rebaixamento, o seu declínio (Untergang), mas não esquece de apresentar também a sua passagem (Übergang), pois o saber é destacado na capacidade de aceitar o mais pesado para surgir a leveza, ou seja, essa vontade de ocaso de Zaratustra visa à dissolução, à destruição, se precipitar, ir ao fundo do mais escuro, no sentido de escapar de si mesmo e alcançar-se novamente com outro rosto e com um novo olhar, mais íntimo e profundo. Pois, o aprendizado e a educação, para serem significativos, não se resumem a resultados quantitativos, há a necessidade de que o indivíduo e até mesmo a cultura, em que ele esteja inserido, se proponham a aceitar o divergente, o

\footnotetext{
${ }^{7}$ A noção de abundância, excesso, supérfluo pode ser uma indicação para a vontade de potência, de expansão e crescimento, de afirmação ativa, construtiva, que deseja a superação.

${ }^{8} \mathrm{O}$ tradutor de Nietzsche em Espanhol, Andrés Sánchez Pascual, esclarece, sobre ocaso (untergang), palavra - chave em Alemão na descrição da filosofia de Zaratustra: "Este verbo em alemão condiz com várias matizes (...) Untergehen, primeiro significa caminhar (gehen), descer, ir para baixo. Em segundo significa pôr -do- sol; 'o ocaso' e por último, Untergehen como substantivo, afundamento, destruição, decadência. Assim é o título da obra de Spengler "Der Untergang dis Abendlands (...). De todas as formas, Nietzsche joga em inúmeras ocasiões com a palavra alemã composta e a contrapõe a outras palavras (...) (SÁNCHEZ. 2002, p.444). Pode-se ver que Nietzsche tanto trabalha com a noção de luz, de esclarecimento, força ativa, como com o lado negativo, reativo, a descida, o ir para baixo até as profundezas. Isto sendo compreendido em dinamicidade, num processo de tensão, de luta, de forças.
} 
contraditório, a profundeza, o conflito, até mesmo aquilo que não quer ser visto. É dessa forma que a vida quer caminhar no limiar da destruição e da construção. O feio, o desconhecido, o nebuloso devem ser vividos pois fazem parte do experimento vital.

Desse modo, há que se mergulhar no labirinto existencial, do que é fracasso, do que não tem riqueza. Mas isso não quer dizer que Zaratustra queira ser visto como mais profundo ou mais prudente do que os outros homens ${ }^{9}$, pois o que o diferencia não é o seu orgulho ou a sua avidez, mas, a sua capacidade de pontuar outro tipo de razão que não seja esta que se contente com a banalidade da vida, ou seja, o seu tipo de razão não aceita a objetividade exacerbada, o modo calculista de viver, pois isso só torna o homem pequeno.

A razão zaratustriana se entranha por uma rede que duela e anseia por uma justificação da destruição geradora, que se elabora e se cria diante do fogo da vida, portanto, não é uma razão objetivada, divinizada, mas inventiva.

Vê-se que o declínio ensina dois movimentos significativos que se configuram conjuntamente: um é o desamor, a ruína, e outro, a travessia, a passagem. A vida se sacrifica porque visa à superação, pois é aniquilando que se pode criar. O lado trágico da vida não pode ser encoberto, ao contrário, deve ser afirmado, pois é através dele que se pode compreender o ponto diverso da constituição humana.

Dessa forma, o mundo pode parecer aberto, para que ele possa ser interpretado e percorrido. Tem-se que desaprender os esquemas que foram inculcados e impostos a todos nós.

Assim, o personagem central insere uma dinâmica a respeito da formação, esta não pode se contentar com as coisas menores, mas nem por isso deve desviar-se delas, pois, elas devem ser o móvel de exigência para que o indivíduo faça a sua ultrapassagem, inclusive do que há de pequeno

${ }^{9}$ Cf: Verificar a tese de Alexandre Belfort Silveira Alves da Silva: O saber no Declínio: A filosofia de Nietzsche à luz de Zaratustra. Departamento de Filosofia. PUC/Rio de Janeiro: 1996. 
em si mesmo. É, por isso, que Zaratustra coloca a importância de sentir o desprezo para que se possa alcançar o verdadeiro sentido do declínio.

$\mathrm{O}$ aprendizado que visa ser demonstrado no declínio é que a sede pela embriaguez da vida, a profusão de conflitos, as necessidades, a procura por ruídos e ruínas podem levar o indivíduo a dizer sempre mais do que antes, porque o segredo de toda grandeza está mesmo em saber conviver com o perigo.

Há, portanto, um contramodelo formativo: se a formação comum quer a solidez, desviar-se do horror, quer configurar certezas, encontrar o progresso, por outro lado, o homem torna-se cada vez mais distinto da contradição, do ocaso, da insegurança e do fracasso, tornando-se um indivíduo fragilizado.

Desse modo, a ideia de formação posta pelo Prólogo não pretende levar ninguém à conformidade. Mesmo se há ideias que mobilizem a superação, isto não quer dizer que se queira fixar uma natureza, pois o próprio sentido de superação não está aprisionado em si mesmo ou na chegada de um telos.

A superação é movimento pelo qual o homem é capaz de superar o que está aí, o que parece fixado; é dessa forma que se pode fomentar a ideia de uma formação para além da formação solidificada, perenizada em normas, leis e deveres já pré-estabelecidos e fora daquele que o constrói.

Nesse processo, mesmo Zaratustra tendo certa segurança da sua própria conduta, não deixa de perguntar para si mesmo: como conviver com os homens sem se perder? Ou refazendo a pergunta: como conviver com um tipo de cultura dos modernos sem se perder? Há um certo receio a respeito de sua descida, mas este será o seu desafio, pois entende que o homem que pretende ver o abismo deve ter forças para ver o abismo de si mesmo. E decide que quer doar um presente para os homens, mas tal doação não vem por esmola.

Entretanto, o que leva Zaratustra a querer estar entre os homens, quando anteriormente isto pode ter sido o motivo de seu afastamento? O que o faz sentir a necessidade de mãos estendidas? $\mathrm{O}$ que o faz querer doar? O que está em excesso? 
Isso nos leva a pensar que a formação de Zaratustra insiste na necessidade de que o homem aprenda a amar mesmo aquilo que parece fora de lugar, só dessa forma pode construir uma excelência. Por isso, a sua ideia de ensinar está ligada àquilo que está excedendo. Então, nos inspira a pensar: se o ensinar tem o seu sentido a partir do excesso, é porque aquele que se põe como educador, ou mesmo que se põe a trocar experiências, antes de tudo deve ser educado, cultivado, para favorecer inspirações, para que seja capaz de instigar a grandeza, a exuberância, especialmente, para si mesmo.

A composição Zaratustriana do Prólogo foge a qualquer tipo de formação para o rebanho; é por isso que ele inspira a necessária atividade de se sujar as mãos, o corpo, tornando-se limpo também pela pobreza, naquilo que é feio, pois é assim que a vida se quer. É na junção da beleza e do horror que o homem pode sentir ainda caos em si mesmo. É na junção da alegria e da tristeza que a vida fomenta seus movimentos.

Então pergunta-se: No Prólogo, Zaratustra se mostra com um ar professoral? Não, como diz Scarlett Marton: as posições que avança tampouco se baseiam em argumentos ou razões; assentam-se em vivências. (...) Recusando teorias e doutrinas, rejeitando a erudição, ele sempre apela para sua experiência singular (MARTON, 2001, p. 29). Antes as suas lições são para si mesmo. Por isso, não é como um condutor de alguém que obtém a verdade, mas como um provocador, que conta a sua própria história diante do experimento de outras histórias, porque ele fala da história das ideias e da cultura. É assim que ele se mostra, e como tal quer fazer o declínio para ensinar aos homens o sentido do seu "ser".

Zaratustra sem nenhum ar professoral nos mostra a imagem da generosidade do pensamento, de alguém que visa doar um presente, que quer trazer um brinde e não imposições, dogmas ou verdades a ser ensinadas. Mas como fazer esse comunicado aos homens? De que forma pode fazer o seu anúncio? 


\section{No Prólogo, como se pode notar, nos discursos sobre o além-do- homem $^{10}$ (Übermensch) e o último homem ${ }^{11}$, Zaratustra realizou}

${ }^{10} \mathrm{O}$ tradutor de Nietzsche em Espanhol, Andrés Sánchez. Pascual, na nota de número 14 de Así Habló Zaratustra, diz que a palavra Übermensch é uma expressão que tem sido muito mal entendida. Pode-se dizer que o além-do-homem não pode ser entendido como uma espécie superior de homem, nem tampouco um homem que vem superar a humanidade toda desconfigurada e empobrecida. Ele representa uma força ativa, uma afirmação criadora, uma disposição à mudança, vista sob o contrário da força reativa, sem vida da cultura moderna, que tende a enfraquecer e aniquilar, representada, para Nietzsche, a partir do rosto do último-homem. O além-do-homem é a força que deseja vencer e afirmar a si mesmo para tornar-se o que se é. Por isso, Nietzsche convida para que sejamos duros, e duros não com os outros, mas conosco mesmos, pois para ter comando, antes é necessária a disciplina. Também a convocação para tornar-se duro não quer dizer sem afetividade. O além-dohomem também não pode ser entendido como um indivíduo transcendental, que quer impor seus valores a outros; ele, como diz Zaratustra, é o sentido da terra, não é uma nova raça, nem um telos a ser seguido, uma finitude, um ideal, pronto e acabado. Assim, o termo será mais bem compreendido no contexto histórico da tradição; fora dele, há leituras racistas do pensamento de Nietzsche quando é sabido que não há conotação política em relação ao termo. O conceito pode ser visto como a própria voz da vida ativa, contrapondo-se aos valores decadentes (SANCHES, P. 2002, p, 445). Na obra "Za/ZA" o termo não faz referência a nenhum emprego anterior do qual seja cunhado o termo, seja em seu aspecto teológico-religioso, seja na concepção romântica do gênio ou mesmo sob a perspectiva do culto ao herói. Parece que Nietzsche quer cunhar o termo a partir da sua própria interpretação, quer dar o seu sentido sobre o termo, que esteja para além das concepções cristãs e até mesmo da romântica.

${ }^{11}$ A figura do último-homem mostra uma humanidade que não tem grandeza, não há caos dentro de si, tudo se encaminha para a tranquilidade e harmonia. Este não sabe o que é criação, o que é amor. Condenado à mediocridade, torna-se igual e uniforme. Isso faz parte de uma cultura minguante, que põe o homem como massa de manobra em todos os sentidos da vida, portanto tal figura é pobre, obediente, contentando-se com pequenas coisas. Tal figura pode ser vista como ameaça para o surgimento de todo tipo elevado. E essa ameaça não passa do resultado representado pela noção do esclarecimento, do racionalismo, da tecnificação da vida e do indivíduo, da mecanização e até mesmo do atrofiamento da sensibilidade, o que leva a um paradoxo: ao mesmo tempo em que a modernidade nos conduz para o avanço da técnica, da ciência e do esclarecimento, ela desemboca num sutil reverso do próprio homem, levando-o ao seu declínio e empobrecimento. Por isso, a noção de progresso, dada pelo trabalho da razão, do cultivo da ciência, se volta, por outro lado, para o homem, com todo o seu teor de perversidade e aniquilamento de todas as suas possibilidades criativas. Nietzsche quer dizer, neste contexto, que parece que o homem só faz se autoconservar, pois é a dimensão instrumental que, demarcada na racionalidade, pontua o ajuste entre meios e fins. A vida e o mundo foram também obscurecidos pelo esclarecimento, aos poucos se foi reduzindo a criatividade, a atividade reflexiva, e, ao 
movimentos de ensino-aprendizagem significativos. $\mathrm{O}$ personagem entende que o seu ensinamento, naquele momento, não pode ser compreendido, os ouvidos do povo do mercado estão embotados. Ele aprende que deve selecionar seus leitores e decide não mais falar para o povo, é necessário discernir o público para consequentemente discernir a mensagem.

O povo não será capaz de compreendê-lo, pois é incapaz de saber o que é grandeza, uma vez que está mais próximo do lodo, da bajulação, do entretenimento, vivendo sob o comando de um niilismo ${ }^{12}$ reativo.

mesmo tempo, ao indivíduo, paulatinamente inibido, restou apenas a possibilidade de viver de forma medíocre.

${ }^{12}$ Para Giacoia Júnior "O niilismo seria a expressão afetiva e intelectual da decadência. Por meio dele, o homem moderno vivência a perda de sentido dos valores superiores de nossa cultura. Por essa ótica, niilismo seria o sentimento coletivo de que nossos sistemas tradicionais de valoração, tanto no plano do conhecimento, quanto no ético-religioso, ou sociopolítico, ficaram sem consistência e já não podem mais atuar como instâncias doadoras de sentido e fundamento para o conhecimento e a ação. Sintomas desse estado de prostração podem ser detectados, segundo Nietzsche, em todos os setores da moderna vida social: na arte, plenamente instrumentalizada para fins de entretenimento, ou, como a chamaríamos atualmente, capturada nos escritos da indústria cultural, na política e na educação, empenhadas em estabelecer e perpetuar um ideal de homem completamente adaptado aos modos de produção e reprodução de uma sociedade de massas; na moral, na ciência e na filosofia, que se tornaram expressões Ideológicas desse desejo de rebaixamento e nivelamento da humanidade, agenciado em escala planetária. Esse movimento de decadência pode ser caracterizado não como um estado permanente, mas como um processo, que pode durar milênios. Um de seus traços mais característicos consiste em que ele inviabiliza a instauração de um contra-ideal, expressão de um movimento ascendente de vida. A decadência se manifesta, sobretudo como ausência de coerção orgânica, como independência e destruição recíproca de elementos e funções, cuja ação conjunta constitui o princípio de unidade na vida de um povo ou cultura. Por essa razão, o traço característico da sociedade moderna é o dilaceramento e a autonomização de seus segmentos constitutivos, o individualismo patológico, que a torna incapaz de se integrar numa totalidade viva, a partir de um projeto ético comum." (GIACOIA, 2000, p. 65). O niilismo também pode ser apresentado em dois momentos, segundo Nietzsche, um passivo (onde o espírito parece adoecer, fica fraco, descontente, regride em potencialidades), que pode apresentar a escalada para um novo estágio que conduzirá ao niilismo ativo, onde o homem, ao mergulhar no fundo de sua existência, encontra forças para transvalorar. Assim, o estágio primeiro de forças reativas passa a construir espaços para a exaltação das forças ativas e criadoras, retirando o homem de tudo àquilo que o rebaixa e o torna pequeno. $\mathrm{O}$ primeiro momento de dor e vazio, da falta de valores para o existir, pode ser entendido como um momento em que as forças regeneradoras tomam contornos alternativos para configurar uma vida forte e soberana. Ainda, o termo Niilismo, segundo Jean Granier, já se 
Para esses homens do entretenimento não há significado nenhum na mensagem de superação, de travessia, de ultrapassagem que Zaratustra argumenta. E como podem realmente ouvi-lo, se ainda não sabem o que é excelência? Pois o homem das letras, o erudito, não passa de um semiculto, de um filisteu e todo o seu saber não foi suficiente para superar o animal bestial que ainda está escondido em si, da mesma forma que toda a sua vestimenta, seu esconderijo dado pela cultura, só faz torná-lo pequeno ao achar que a razão pode levá-lo ao topo do mundo. Esse homem é digno ainda de riso. Esses homens não têm descoberta, não têm necessidade de pensar, de trabalhar a criação, antes, são homens que mergulham no espetáculo e na alienação de suas próprias vidas, negando para si mesmos a possibilidade de se perceber diferentes, isso Zaratustra aprende. Contudo, é este pensar que os faz saltitar de um lado para o outro, sem objetivos, perdidos entre cores e máscaras, entre disfarces e crenças, entre demônios e deuses.

Zaratustra reconhece que não soube fazer uma boa escolha. E entende que os homens do mercado ${ }^{13}$ estavam preocupados com a tagarelice, com a banalidade, com o conforto momentâneo, com os gestos rudes. E, por isso, se apresentavam de maneira arrogante e indiferente.

encontra em Jacobi, Jean Paul, Turgueniev, Dostoievski, nos anarquistas russos, que Nietzsche o toma de Paul Bourget, em que serve para designar a essência da crise mortal em que o mundo moderno está envolvido. Sobre essa última informação utiliza-se a tradução retirada do site de "Nietzsche en Castellano", 05/06/2003. Como se pode ver, o termo, apesar de ter tido conhecimento popular em Nietzsche, não foi só usado por ele. Sobre essa temática há uma recente publicação da coleção Sendas e Veredas, cujo título é Niilismo, criação e aniquilamento: Nietzsche e a filosofia dos extremos de Clademir Luis Araldi, que traz um leque ampliado de informações sobre essa questão, tão importante na filosofia nietzscheana.

${ }^{13}$ Este é um lugar significativo para Zaratustra, podendo ser visto como um espaço público de encontro, ou como a própria feira, aquilo que se vende e compra, o lugar do comércio, do negócio, da troca. Em Zaratustra este lugar mostra especialmente o lugar de penúria e depreciação do homem, aquilo que foi degenerado pela compra e a venda. O lugar onde a palavra é esquecida, a linguagem não é entendida, e os gestos rudes são expostos. $\mathrm{O}$ homem foi se perdendo e cada vez mais tornou-se empobrecido e vulgar. É no mercado que Zaratustra entende que a pobreza é comercializada e vendida. Sobre essa questão, Christoph Türcke, no seu livro Nietzsche: O louco: Nietzsche e a mania da razão, faz uma interpretação bastante interessante. 
Então, se, no primeiro momento, o seu ensino era para todos, no final do seu discurso ele se mostra mais seletivo.

Zaratustra compreende que a tarefa de vencer o niilismo pode ser negada pelo bem-estar prometido, pelo prazer da diversão do mundo moderno. Assim, o fracasso de Zaratustra é um "aparente fracasso" ou um "fracasso parcial", já que a partir dele houve um aprendizado: ele aprende que o homem com quem estava dialogando ainda não está preparado para ouvi-lo e entendê-lo; o fenômeno da banalidade, os gestos vulgares são algo marcado na cultura moderna e isso ele pretende evidenciar, pois este é um projeto de vida da cultura massificada. Essa figura pequena é um sintoma de total decadência ${ }^{14}$, e, portanto, a tarefa formativa/cultural de

\footnotetext{
${ }^{14}$ Sobre a questão da decadência, este é um termo de ordem fundamental na filosofia de Nietzsche. Este termo foi utilizado por Paul Bourget que o põe mais no sentido literário e que Nietzsche retoma dessa forma e depois amplia no seu livro "O Caso Wagner, § 7" " Como se caracteriza toda a decadência literária? Pelo fato de a vida não mais habitar o todo. A palavra se torna soberana e pula fora da frase, a frase transborda e obscurece o sentido da página, a página ganha vida em detrimento do todo - o todo já não é todo. Mas essa é uma imagem para todo estilo de decadência: cada vez mais, anarquia dos átomos, desagregação da vontade, "liberdade individual", em termos morais - estendendo-se à teoria política, "direitos iguais para todos". A vida, a vivacidade mesma, a vibração e exuberância da vida comprimida nas mais pequenas formações, o resto pobre de vida. Em toda parte paralisia, cansaço, entorpecimento ou inimizade e caos: uns e outros saltando aos olhos, quanto mais ascendemos nas formas e organização. $\mathrm{O}$ todo já não vive absolutamente: é justaposto, calculado, postiço, um artefato" (NIETZSCHE, 1999, p.22). Pode-se conferir ainda a nota de número 27 da tradução de Paulo César de Souza, da mesma obra citada acima, que Nietzsche, "em um 'fragmento póstumo' do início de 1888, um esboço desta preocupação encontra-se o nome de Paul Bourget, ensaísta francês admirado por Nietzsche. E já foi observado que esta frase é quase uma tradução do seguinte trecho de Essays de psychologie contemporaine, de Bourget (Paris, 1883) Une méme loi gouverne le développement et la décadence est celui où l'unité du livre se décompose pour laisser la place à l' indepédennce du mot ( apud Colli e Montinari, KSA, vol. 13”. (SOUZA. 1999, p. 85) Há um texto bastante interessante que remete a essa questão de Wolfgang Müller-Lauter: Décadence artística enquanto décadence fisiológica. Há também a proposta da crítica tardia de Friedrich Nietzsche a Richard Wagner. Cadernos Nietszche, n. 6. 1999). É bom ressaltar que a decadência se manifesta com um estado de forças, em que a vontade que domina preza pela desagregação, enquanto a dominada quer sempre conservar. $\mathrm{O}$ movimento de decadência pode ser compreendido como estado permanente, o qual pode ser pensado como processo que tem longa duração diante da história. Pode-se dizer que o mundo e a sociedade modernos encontram-se em desagregação, sendo, então, incapazes de operar diante da totalidade vital. Mas o processo de decadência anuncia o constante movimento de negação, de declínio de todos os valores até então vigentes, e vai procedendo para um
} 
nosso tempo se torna cada vez mais urgente, já que a degradação e a perspectiva desestruturante tomam conta de todos os ramos da vida, até mesmo no aspecto valorativo, moral e ético.

No fundo, o maior fracasso foi dos homens do mercado, que não compreenderam sua comunicação, e não propriamente de Zaratustra. Com essa experiência com o povo do mercado, Zaratustra também aprende que existe outro modo de compreensão da vida e que a sua interpretação não poderia ser entendida naquele momento, existia outra demanda de interesses, o que nos leva a entender que muitas vezes o professor impõe a sua verdade, a sua interpretação de mundo e negligencia outras interpretações.

A comunicação foi fundamentalmente formativa, tanto para ele como para seus leitores, em um duplo movimento: no primeiro, Zaratustra é educado pelo "fracasso" de sua comunicação, que não foi em si um fracasso; no segundo, ele nos educa porque nos leva a pensar sobre que perspectiva o homem está inserido e em que medida quer avançar sobre si mesmo, ou seja, se quer ainda o rastejante, o liquidado em amor e paixão, ou se quer ter uma vontade afirmativa.

O sentido afetivo que traz o diálogo zaratustriano é forte, desconcertante, apresenta o que ainda se vive, ao mesmo tempo em que

movimento de aniquilação, ele procura se contrapor às forças antivida, que são dominantes. Contudo, são forças que não criam, são tipos afirmativos que desejam apenas a conservação, são incapazes de instituir novos valores, só revertem o seu sentido, por isso diz Giacoia que "Inversão e oposição constituem sua dynamis." (GIACOIA J, O. 1997, p. 22). Para Nietzsche a história da ascensão e do declínio vem se manifestando juntamente com o traço da decadência. A dinâmica da reversão e oposição é a própria explicação do sentido constituinte das oposições, contudo, elas estão em tensão, em luta constante, desejando impor o seu comando, a sua vontade, seja reativa ou ativa, conservadora ou construtora de novos valores. O seu movimento é conduzido pela vontade niilista, a vontade de nada, mas sendo uma vontade, não chega a querer dominar, impor a sua força e o seu querer, acaba resultando em sua ambiguidade, em que o nada não pode ser compreendido sem o nada da vontade. Portanto, mesmo a vontade de nada tem a sua potência. Dessa forma, a vontade negativa também triunfa sobre a vontade de morte. Contudo, sua natureza é vontade que quer a luta, a força, ela mesma não quer a conservação, mas o movimento constante. Desse modo, a vida minguante, decadente, não deixa de se mover contrariamente, sendo que deste movimento pode emergir a sua vontade criadora. 
mostra que o homem moderno deve assumir a sua autodeterminação. Há cada vez mais a necessidade de projetar um ser humano que possa estar preparado para uma tarefa de grande responsabilidade. Ainda, o diálogo com o povo do mercado é formativo uma vez que Zaratustra entende que a sua comunicação está para além daquele homem do presente.

Agora, no final do Prólogo, não se mostra mais como um doador, um presenteador, mas como um denunciador, um crítico. Aprende que sua comunicação não é para aqueles homens de gestos vulgares, que estalam as línguas, ou seja, demarca a distância sobre o homem do seu tempo, mostrando que seu diálogo é extemporâneo. Contudo, reconhece que, apesar de tudo, sua alma está serena, embora o povo ache que ele é apenas um zombador. Mudado, pelo seu próprio experimento, dá-se conta de si e dos outros, e, portanto, educa-se, e, por outro lado, inspira aqueles com disposição para educar-se também.

\section{III}

Depois de presenciar uma cena com o povo, aparece um saltimbanco que caminha sobre a corda que está entre duas torres, suspensa sobre a praça e o povo; no meio da corda vem um bufão exigindo que o saltimbanco saia do caminho, mas este se aproxima e pula por cima dele fazendo-o perder o equilíbrio. É exatamente perto de Zaratustra que o saltimbanco se "espatifa" no chão. Após este fato, todo o povo começa a sair da praça, mas Zaratustra não se move. Este será, então, o primeiro companheiro de Zaratustra, embora morto. Ao anoitecer, a praça do mercado fica envolta em uma grande escuridão, configurando a primeira escuridão por que passa o personagem central, mas Zaratustra permanece sentado, e sobre a noite vem um vento frio. Ele resolve levantar e diz:

Em verdade, uma bela pescaria teve hoje Zaratustra! Nenhum homem pescou, e sim um cadáver". Inquietante é a existência humana, e ainda sem sentido algum: um palhaço pode lhe ser uma 
fatalidade. Quero ensinar aos homens o sentido do seu ser: que é o super-homem, o raio vindo da negra nuvem homem. Mas ainda me acho longe deles, e meu sentido não fala a seus sentidos.(NIETZSCHE, 2011, p. 21)

A sua mensagem não é para aquele momento. Assim, toda a primeira parte é um presente que está no futuro. Nesta passagem, é importante notar que, curiosamente, aquele cadáver, o homem morto, suscitou ao Zaratustra reflexão: dialogou com ele, fez meditações, pois ele disse muita coisa da condição humana.

O cadáver é uma metáfora utilizada por Zaratustra para dizer que os homens com quem tentou dialogar, comunicar uma certa sabedoria, estão fechados em si mesmos, enclausurados em suas concepções, estão efetivamente mortos para saber receber outras vivências, sentir outras experiências.

Toda a sua tentativa para descrever e demonstrar uma existência liberta que pudesse conduzir o homem para o seu próprio destino não fora compreendida. Sendo assim, o cadáver é o homem que perdeu os sentidos, a sensibilidade, é o tipo acabado, incapacitado de fazer aberturas. Ele vai se dando conta da sua distância diante daqueles homens do mercado, que já estão fossilizados em seus saberes.

Mas, no fundo, gostaria de dialogar com um homem aberto para a vida, porém, eis que se abateu sobre ele um morto, o tipo moderno, que já não pensa, não quer discutir, não tem nenhuma tensão dentro de si, por isso mesmo é um cadáver. Zaratustra o põe nas costas e começa a caminhar. Após poucos passos, um homem o cerca e murmura algo em seu ouvido. Quem fala é o bufão, que pede para Zaratustra deixar a cidade o mais depressa possível, pois são muitos os que o odeiam. Odeiam-te os bons e justos, e te chamam de seu inimigo e desprezador; odeiam-te os crentes da verdadeira fé, e te chamam o perigo para a multidão (NIETZSCHE, 2011, p. 21).

Zaratustra percebe que seu discurso chegou a ser inoportuno, indesejado. O bufão se põe como aquele que representa o corpo do último- 
homem. E, sob o cenário da diversão, onde o homem se encontra, Zaratustra encontra outra "verdade". Ele demora, reflete, não se deixa ser sucumbido. Por isso, dorme e acorda sob a aurora. Admirado, olha a floresta, sente também o silêncio, e olha para si mesmo. Levanta depressa e vê uma nova verdade, ou seja, aprende que de companheiros ele precisa, mas não mortos, pois não são discípulos submissos, sem voz, sem fala, que ele quer.

Uma luz raiou em mim: de companheiros necessito, de vivos - não de mortos e cadáveres, que levo comigo para onde quero ir. Mas de companheiros vivos necessito, que me sugam porque querem seguir a si mesmos (...). Companheiros é o que busca o criador, não cadáveres, e tampouco rebanhos e crentes. Aqueles que criam juntamente com ele busca o criador, que escrevam novos valores e novas tábuas (...) (NIETZSCHE, 2011, p. 24).

Nesse contexto, Zaratustra reporta-se para o perfil do afirmador e criador, deste ele pretende agora se tornar companheiro. Ou seja, longe da massa, daquele tipo uniforme, pois estes não podem ser seus discípulos. Zaratustra não é nenhum pastor e não quer ser nenhum rebanho. Não deverei ser pastor, nem coveiro. Jamais tornarei a me dirigir ao povo; pela última vez, falei com um morto, e diz ainda: Quero juntar-me aos que criam, que colhem, que festejam (...) (NIETZSCHE, 2011, p. 24).

O conteúdo formativo de Zaratustra é exemplar, pois aquele que pretende ser livre e senhor não pode também aprisionar, visto que este feito seria a sua própria prisão. Não quer companheiros mortos, mas vivos, que o sigam, porque antes de tudo deseja seguir a si mesmo. O seu aparente fracasso ou o seu fracasso parcial lhe revelou outra perspectiva de relação, e, portanto, de formação, não quer ser um cão de rebanho. O seu papel formativo nesta fala é colocar muitos para fora do rebanho, é neste sentido que se faz educativa.

Agora, quer unir-se aos que criam e não ao povo. Portanto, podese dizer que do aparente ou parcial fracasso emergiu um novo aprendizado, ele educou-se. O educador, pode-se dizer, a partir dessa experiência de 
Zaratustra, não pode querer rebanhos, antes, o mestre deve ser a favor de que os discípulos o superem, pois os crentes, os servidores, são de certa forma como cadáveres que precisam ser carregados. $O$ mestre deve apreciar companheiros vivos, instigantes, descobridores, pois, dessa forma, eles podem trocar experiências e vivências.

Zaratustra "aprende" gradativamente a necessidade de selecionar e sai da perspectiva de um doador para um homem mais prudente. Como mestre não pretende ser divinizado, nem muito menos imortalizado. Antes de tudo, ele quer "sucumbir" e o discípulo em justa medida deve saber assassiná-lo para poder avançar, ir adiante. Não é como um sujeito objetivado que quer ser visto, nem como uma figura paterna, com uma voz do comando, da norma e da lei. Pois, o sujeito que deseja escrever a sua singularidade deve necessariamente sustentar sua palavra, orientar-se por si mesmo, elaborar seus sinais, efetivar sua passagem. Nesse caso, Zaratustra tenta justificar os criadores, sem idealizações: eles são inventores, sobretudo de si mesmos.

No último item do Prólogo, ele fala do meio-dia, hora dos mais criativos, dos mais seletos: seria o momento da tomada de consciência, em que ele vai ter que passar por outras experiências e tomar outras atitudes. Zaratustra fala com seus animais, a águia e a serpente, já remetendo à noção do eterno retorno ${ }^{15}$. Em círculos, a águia está com uma serpente enrolada no pescoço, não como inimiga, mas como amiga, como numa aliança, simbolizando de maneira mais radical a superação de todas as dualidades. E assim o ocaso de Zaratustra é iniciado.

\section{Referências}

ARALDI, C. L.. Niilismo, criação, aniquilamento: Nietzsche e a filosofia dos extremos. São Paulo: Discurso editorial; Ijuí, RS: Editora UNIJUÍ, 2004.

\footnotetext{
${ }^{15}$ Sobre a doutrina do eterno retorno e da vontade de potência, Zaratustra parece conservar certo silêncio, aquilo que ele põe como tema central de seu livro aparece sempre de maneira acanhada.
} 
DICIONÁRIO: Hauaiss da língua portuguesa. Rio de Janeiro: Objetiva, 2001. https://doi.org/10.5628/rpcd.01.03.03

GIACOIA JUNIOR, O. Nietzsche. São Paulo: Publifolha, 2000.

- Labirintos da alma: Nietzsche e auto-supressão da moral. Campinas/ SP: Editora da UNICAMP, 1997.

JANZ, C, P.. Friedrick Nietzsche; infância y juventude. Tradução. Jacob Muños. Madrid: Alianza Editorial, 1994.

. Friedrick Nietzsche; los diez años de Basiléia. 1869/1879. Tradução. Jacob Muños. Madrid: Alianza editorial, 1987.

- Friedrick Nietzsche; los diez años como filósofo errante 1879/1888. Tradução. Jacob Muños. Madrid: Alianza editorial, 1994.

LAÜTER-MÜLLER. W. Décadence artística enquanto décadence fisiológica: A propósito da crítica tardia de Friefdrich Nietzsche a Richard Wagner. Tradução: Scarlett Marton. Cadernos Nietzsche. n. 6, 1999.

. The Way To the Overman. In: Nietzsche his philosophy of contradictions and the contradictions of his philosophy. Translated from the Germasn by David J. Parent. University of Illinois Press. Urbana and Chicago, 1999.

MACHADO, R. Zaratustra: tragédia nietzscheana. Rio de Janeiro: Jorge Zahar Ed, 1997.

MARTON, S. Em busca do discípulo tão amado: Uma análise conceitual do prólogo de Assim Falou Zaratustra. In: Revista Impulso. vol. 12, n. 28. Piracicaba: Editora UNIMEP, 2001.

NIETZSCHE, F. Así habló Zaratustra: Un libro para todos y para nadie. Introducción, traducción y notas de Andrés Sánchez Pascual. Madrid: Alianza Editorial, 2002. 
Assim Falou Zaratustra: um livro para todos e para ninguém. Tradução, notas e posfácio: Paulo César de Souza. São Paulo: Companhia das Letras, 2011.

- O caso Wagner: Um problema para músicos. Tradução, notas e posfácio de Paulo César de Souza. São Paulo: Companhia das letras, 1999.

SILVA, A. B. S. da. O saber do Declínio: A filosofia de Nietzsche à luz de Zaratustra. Departamento de Filosofia da PUC/Rio de Janeiro: 1996. (tese de doutorado).

SUFFRIN-HÈBER, P. O Zaratustra de Nietzsche. Tradução. Lucy Magalhães. Rio de Janeiro: Jorge Zahar Ed, 1994.

TÜRCKE. C.. O louco: Nietzsche e a mania da razão. São Paulo: Vozes, 1993. https://doi.org/10.1021/jo00069a026

YAFAR, A. R. O ateísmo como vontade de ocaso. Cadernos Nietzsche. São Paulo: n. 11, 2001.

Data de registro: $30 / 01 / 2020$

Data de aceite: $27 / 05 / 2020$ 